\title{
RESEARCH ON ECOSYSTEM HEALTH ASSESSMENT INDICES AND THRESHOLDS OF A LARGE YANGTZE-CONNECTED LAKE, POYANG LAKE
}

\author{
ZHANG, Y. H. ${ }^{1,2}-$ YANG, G. S. ${ }^{2,3^{*}}-$ WAN, R. R. ${ }^{2,3^{*}}-$ ZHU, H. Y. ${ }^{1}$ \\ ${ }^{1}$ Nanjing Xiaozhuang University, Nanjing 211171, P. R. China \\ ${ }^{2}$ Key Laboratory of Watershed Geographic Sciences, Nanjing Institute of Geography and \\ Limnology, Chinese Academy of Sciences, Nanjing 210008, P. R. China \\ ${ }^{3}$ University of Chinese Academy of Sciences, Beijing 100049, P. R. China \\ *Corresponding authors \\ e-mail: gsyang@niglas.ac.cn; rrwan@126.com
}

(Received 22 $2^{\text {nd }}$ Apr 2019; accepted $12^{\text {th }}$ Jul 2019)

\begin{abstract}
Assessing the aquatic ecosystem health status of lakes has been the focus of lake studies for domestic and overseas researchers and water resource managers. Poyang Lake, which is one of the only two remaining large Yangtze-connected lakes in the middle reaches of Yangtze River in China, provides considerable ecosystem service functions, such as flood water storage, water supply for industrial and agricultural production, maintenance of the unique and diverse biota of the entire Yangtze floodplain ecosystem, maintenance of regional ecological balance and so on. However, due to the impact of climate change and human activities, Poyang Lake has experienced drastic hydrological changes, water quality decline and aquatic ecological function degradation in recent years. An assessment of the aquatic ecosystem health of Poyang Lake is of great importance. On the basis of the index system construction principles and a meta-analysis of previous research, this paper puts forward the index system for the ecosystem health assessment of Poyang Lake. The indices contains the three element layers of aquatic organisms, hydrologic characteristics and trophic status and the five indicators of ratio of cyanobacteria biomass to diatom biomass (CB/DB), diversity index of macrozoobenthos, lowest water level anomaly during the dry season, mean water level anomaly during rising season and trophic state index (TLI). Then, the thresholds of indicators are determined using empirical study, frequency analysis, standard specification and so on. Aquatic ecosystem health status is categorised into three groups: 'good', 'moderate' and 'poor'. The study could provide theoretical basis for identifying the causes of the lake aquatic ecosystem health degeneration and protecting the environment of Poyang Lake. This present study provides an attempt to quantify the aquatic ecosystem health in a large floodplain lake with dramatic hydrological variations and will give some impetus for floodplain ecosystem assessment and management worldwide.
\end{abstract}

Keywords: aquatic ecosystem health, physical-chemical-biological index, hydrologic indicators, ratio of cyanobacteria biomass to diatom biomass, thresholds, large Yangtze-connected lakes, Poyang Lake

\section{Introduction}

The global ecosystem has become increasingly destroyed since the 1960s, and human society is facing immense challenges concerning survival and development (Zeng et al., 1999). Ecologists have begun to pay attention to the issue of ecosystem health. In 1988, Schaeffer proposed the concept of ecosystem health measurement (Schaeffer et al., 1988), and domestic and foreign scholars have since initiated substantial research on the concept of ecosystem health and related concerns (Costanza et al., 1992; Rapport and Whitford, 1999). Ecosystem health assessments are common in the research fields of forests, rivers, oceans, wetlands and so on (Cui and Yang, 2002; Borja and Dauer, 2008; Davies et al., 2011). Lakes, as a crucial part of the terrestrial 
surface system, serve as vital freshwater reservoirs and help conserve species gene pools on earth; they are also known for their ecological functions, including maintaining ecological balance of basins, supplying production and living water, and providing rich aquatic products, and thus have great ecological and economic significance to regional development (Yang et al., 1988). Since the introduction of the ecosystem health concept in the 1980s, the health assessment of lake aquatic ecosystems, as a key part of lake ecosystem management, has gradually become the focus of scholars, resource managers and environment managers at home and abroad (Xu et al., 2001, 2012; Kane et al., 2009). Ecosystem health assessment provides the theoretical basis for analysing the causes of lake ecosystem health degradation and the protection of lake water environment, which is also closely linked with the achievement of the virtuous cycle of lake ecosystems.

Many scholars at home and abroad have performed studies regarding the construction of the assessment index system and the determination of thresholds because they are crucial in the health assessment of lake aquatic ecosystems. The selected assessment indices mainly include two aspects. The first aspect on biological components, e.g. biomass, species, diversity indices, etc. (Xu et al., 2001; Jeppesen et al., 2011; Umi et al., 2018); Phytoplankton and macrozoobenthos are commonly selected for ecosystem health assessment (Lyche-Solheim et al., 2013; Sreeja, 2018). Eutrophication responses are mainly evaluated on phytoplankton, macrozoobenthos and large aquatic plants, whilst $\mathrm{pH}$ response is mainly assessed by macrobenthos and fish (Solheim et al., 2008); Large aquatic plants (Mjelde et al., 2013; Keto et al., 2006), macrozoobenthos (Baumgärtner et al., 2008), and fish (Sutela and Vehanen, 2008)) have been used to describe responses to hydromorphological alterations. The second aspect represents the systematic indices, which are constructed from aquatic biological components, such as eco-exergy, structural eco-exergy, ecological buffer capacity, entropy, etc. (Ludovisi, 2006; Ludovisi and Poletti, 2003; Kane et al., 2009). The primary assessment approaches include the comprehensive health indices $(\mathrm{Xu}, 2005$; Shuai and $\mathrm{Li}, 2014$ ) generated by index system weighting or algorithmic derivation and the water quality model-based method (Xu et al., 2013; Zhang et al., 2010; Banerjee et al., 2017; Qi et al., 2018). Poyang Lake is one of the only two remaining large Yangtzeconnected lakes in the middle reaches of Yangtze River in China. Its ecosystem development is affected not only by pollutants and sediments within the lake but also by seasonal hydrological fluctuations, particularly the annual amplitudes of water levels that reach $8 \mathrm{~m}$ (Zhao and Tong, 2013), which can significantly affect lake structures and functions (Coops et al., 2003). In recent years, Poyang Lake has also been affected by ecological and environmental issues related to human activities. Water quality has declined and eutrophication has gradually increased, and these phenomena resulted in ecological problems such as potential hazards of cyanobacterial bloom breakout (Yang, 2012; Cheng and Li, 2006; Xu et al., 2012; Li et al., 2017; Zhang et al., 2018). Therefore, constructing a lake aquatic health assessment index system suitable for the hydrological variation characterisation of Poyang Lake and large Yangtze-connected lakes, scientifically determining assessment indicator thresholds, and evaluating lake aquatic ecosystem health are of great theoretical and practical significance. On the basis of the analysis of the ecological system and evolution characteristics of Poyang Lake, this study combines observed and acquired data to construct a preliminary aquatic ecosystem health assessment index for large Yangtze-connected lakes. Then, the aquatic ecosystem health assessment thresholds are determined by adopting the special value 
method, frequency analysis method, normative standards and analogies, reference mode method and so on.

\section{Materials and methods}

\section{Study area and data}

Physical, chemical and biological variables were measured in Poyang Lake from 1984 to 2013. Data from 2007 to 2013 were supplied by the Lake Poyang Laboratory for Wetland Ecosystem Research of the Chinese Ecosystem Research Network, whilst other less and reference data were collected from previous studies (Committee, 1993; Xie et al., 2000). Water level data from 1951 to 2011 were collected from the Changjiang (Yangtze River) Water Resources Commission. The details of these datasets are shown in Table 1 and Figure 1.

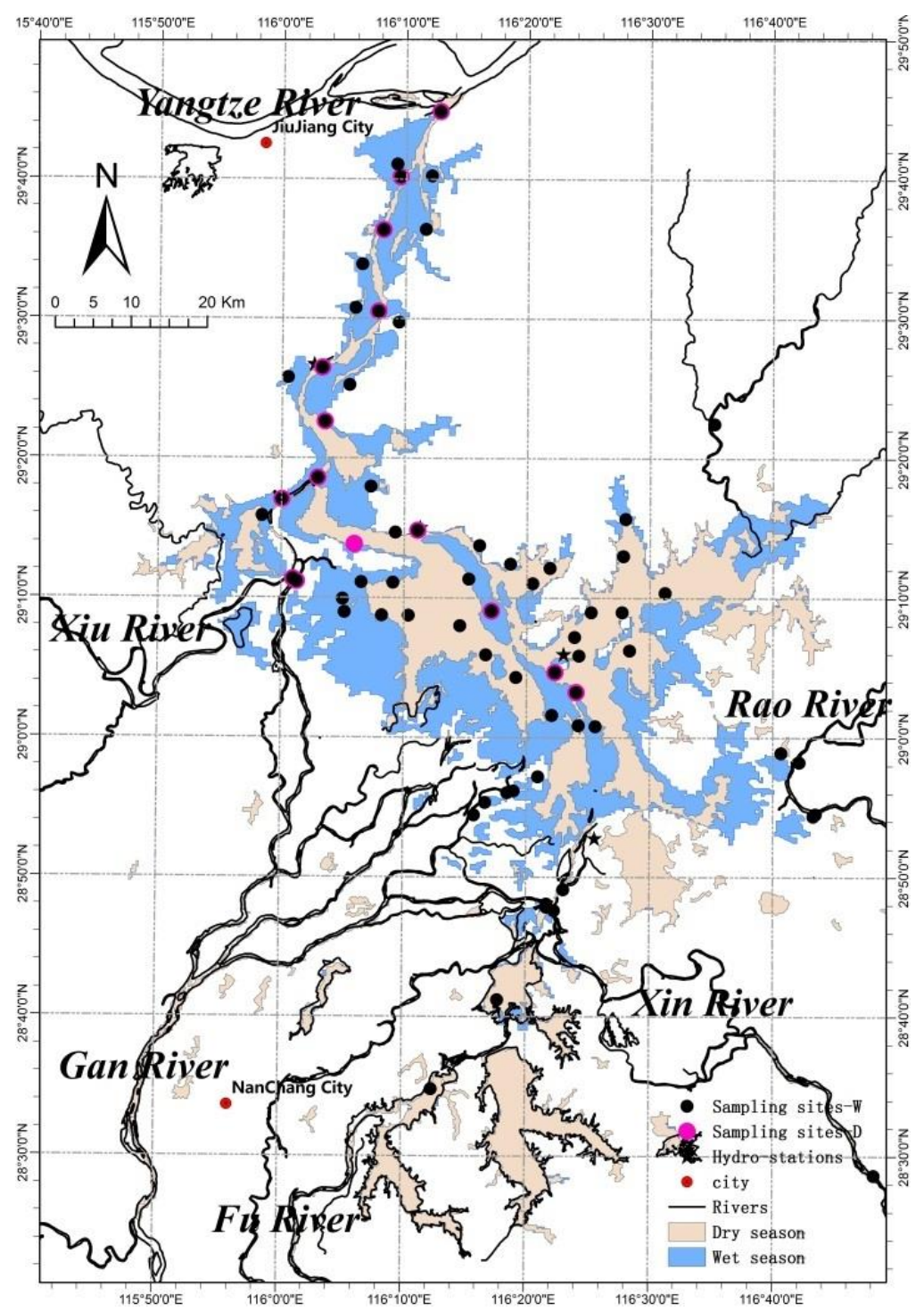

Figure 1. Location and sampling sites of Poyang Lake

Notes: Sampling sites-D: sampling sites in dry season, Sampling sites-W: sampling sites in wet season 
Table 1. Summary of variables and number of sites sampled in a given month and year in Poyang Lake

\begin{tabular}{|c|c|c|}
\hline Year & Month and sites & Data \\
\hline $\begin{array}{c}1984, \\
1987-1993 \\
\end{array}$ & $\begin{array}{l}\text { Details shown in previous studies } \\
\text { (Committee, 1993; Xie et al., 2000) }\end{array}$ & $\begin{array}{l}\text { Biological variables (density of phytoplankton, } \\
\text { etc.) }\end{array}$ \\
\hline 2007 & October, 24 sites & \multirow{3}{*}{$\begin{array}{l}\text { Physical, chemical and biological variables } \\
\text { (SD, TN, TP, COD }{ }_{m n}, \text { Chl-a, biomass and } \\
\text { density of phytoplankton, macrozoobenthic) }\end{array}$} \\
\hline 2008 & June, 35 sites & \\
\hline 2009-2011 & January, April, July and October, 15 sites & \\
\hline 2012 & $\begin{array}{l}\text { January, April and October, } 15 \text { sites } \\
\text { July, } 97 \text { sites }\end{array}$ & \multirow{2}{*}{$\begin{array}{l}\text { Physical, chemical and biological variables } \\
\left(\mathrm{SD}, \mathrm{TN}, \mathrm{TP}, \mathrm{COD}_{\mathrm{mn}}, \mathrm{Chl}-\mathrm{a} \text {, biomass and }\right. \\
\text { density of phytoplankton, macrozoobenthic) }\end{array}$} \\
\hline 2013 & July, 106 sites & \\
\hline $1951-2011$ & $\begin{array}{c}\text { January-December, seven sites (Xingzi, } \\
\text { Duchang, Hukou, Kangshan, Wucheng, } \\
\text { Tangyin and Boyang) }\end{array}$ & Water level \\
\hline
\end{tabular}

SD: Secchi disk depth (water transparency); TN: total nitrogen; TP: total phosphorus; $\mathrm{COD}_{\mathrm{mn}}$ : chemical oxygen demand; Chl-a: chlorophyll a

\section{Methods}

The construction of the aquatic ecosystem health assessment index system for in this study was mainly determined on the basis of literature research and theoretical analysis. The primary approaches for determining the index thresholds can be divided into two categories, namely, through statistical analysis approaches, such as the frequency analysis method and the special value method, direct observation of reference state and the adoption of normative standards. All statistical analyses were performed with the Statistical Program for Social Sciences (SPSS-IBM, New York, NY) 13.0 software.

\section{Results and discussion}

\section{Construction of aquatic ecosystem health assessment index system for Poyang Lake}

Many studies have demonstrated that the health status of lake aquatic ecosystems of water bodies should be assessed from the perspective of biological elements and supporting hydro-morphological and physico-chemical elements, especially water levelrelated indices (Mjelde et al., 2013), and not only on the basis of some specific biological, physical or chemical indices (Xie et al., 2013; Xu et al., 2013; Ghosh et al., 2018). Therefore, as a large-scale Yangtze-connected lake, the construction of an aquatic ecosystem health assessment index system for Poyang Lake must also consider the status of biological elements and supporting hydromorphological and physicochemical elements.

\section{Biological indicators}

Lake ecosystems mainly include aquatic organisms such as planktons, benthic organisms, large aquatic plants and fish, etc. The indicators most widely used are biomass, quantity, species structure, and so on. On the basis of the response of various aquatic organisms to stress and the aquatic characteristics of Poyang Lake, phytoplankton and macrozoobenthos are selected to characterise the lake's aquatic ecosystem health. 
(1) Phytoplankton: Phytoplankton is a critical indicator for the health assessment of lake aquatic ecosystems. Changes in algal species structure can reveal variations in the water environment (eutrophication, etc.) and lake ecosystems (Vanni, 1987; Paerl et al., 2013). The hydrological regime will affect the biomass, species composition, diversity and succession of phytoplankton (Wu and Guo, 2001). Lotic ecosystems are dominated by diatoms, whereas lentic ecosystems are dominated by cyanobacteria (De Emiliani, 2001). Relative to Taihu Lake, the phytoplankton characteristics in Poyang Lake are dominated by diatoms in the aspects of biomass and quantity, not cyanobacteria (Xu, 2013; Wu et al., 2013). But cyanobacteria bloom was also found at the centre part of the lake in 2011 (Xu, 2013). Dam construction in Poyang Lake has become controversial in recent years because of its adverse effects to water level fluctuations, and consequently, to the structure of phytoplankton (Liu et al., 2015). Many scholars have predicted the outbreak of cyanobacteria bloom after dam construction. Algal structural changes, particularly variation tendency in cyanobacteria proportion, are the primary focus of aquatic ecosystem health assessments for Poyang Lake. Constructing the ratio of cyanobacteria biomass (CB) to diatoms biomass (DB) can help determine the water environment of Poyang Lake and its aquatic ecosystem health characteristics.

(2) Macrozoobenthos: Macrozoobenthos are essential indicator organisms for monitoring human disturbance and lake pollution and thus ideal as natural monitors. The diversity index of macrozoobenthos has been widely adopted for the water pollution assessment of lakes and rivers (Shuai and Li, 2014; Xiong et al., 2003; Miler et al., 2013). The EU Water Framework Directive uses macrozoobenthos to monitor and evaluate the ecological health of lakes, as they are sensitive to water level amplitudes (i.e. water levels affect the abundance of macrozoobenthos) (Aroviita and Amalainen, 2008). The density of macrozoobenthos in Poyang Lake has drastically changed in recent years, as evidenced by the obvious decrease of molluscs (Cai et al., 2014), whilst the increased number of large animals have negatively affected the abundance of small marsh and long-horned snails (Ou et al., 2009). Large-scale sand mining and river scouring have also altered the macrozoobenthos habitat and influenced their community structures in recent years. Therefore, macrozoobenthos characterisation has been prioritised in the aquatic ecosystem assessment of Poyang Lake, and the diversity index of macrozoobenthos has been selected as the biological indicator.

Large aquatic plants and fish are also vital indicator species of aquatic ecosystem changes in Poyang Lake. However, large aquatic plants only appear in few branch areas of the lakes during the summer flooding season (Jian et al., 2015), and for the structure of fish species, there are certain similarities between Poyang Lake and Yangtze River Basin and the whole country (Hu, 2009). Hence, in this paper, we will not include large aquatic plant and fish species, considering their representativeness and substantial data availability.

\section{Hydrological indicators}

Habitat is commonly characterised on the basis of the following aspects: hydrology, water environment, lake morphology, and human activity or interference. The hydrological elements of Poyang Lake are relatively unique. For instance, water-level fluctuations are significant during the year, which greatly impact the lake's ecological environment. Subsequently, wetland area and distribution are directly affected, whilst the growth of aquatic organisms (e.g. phytoplankton and fish) are either directly or 
indirectly affected. Therefore, hydrological element is selected as one of the habitat indicators for the aquatic ecosystem health assessment of Poyang Lake.

Previous studies have proposed that the indices for water level fluctuations include winter water level amplitude and spring flood amplitude (Hellsten, 2001; Keto et al., 2006, 2008; Mjelde et al., 2013), as they affect the species abundance of large aquatic plants (Keto et al., 2006), macrobenthos (Aroviita and Amalainen, 2006) and fish (Sutela and Vehanen, 2006). The communities of carex-polygonum criopolitanum, carex-Phalaris arundinacea and Phalaris arundinacea-carex in Poyang Lake are relatively sensitive to changes in water level conditions and largely affected by water level amplitudes (Zhang et al., 2012), and they have low tolerance to changes in hydrological conditions. The seasonal droughts in spring (rising season) and winter (dry season) over Poyang Lake in recent years have caused serious impacts on the wetlands and aquatic ecosystems of the lake (Yang, 2012). For instance, spring drought is disastrous to fish, as they lay eggs in large quantities due to the simulation of gonads by flowing water and aquatic plants. If the aquatic plants are exposed to non-water areas during April and May, fish reproduction will be seriously affected. The lowest water level during the dry season directly impacts the growth and distribution of wetland plants and the succession of vegetation belts, thus affecting the different ecosystem functions (e.g. wetland ecological function and migratory bird habitat function) of Poyang Lake (Hu et al., 2012). The lowest water level during the dry season will also influence the habitat of migratory birds, and its occurrence is averse to their protection (Qi and Zhang, 2014). Characterising the lowest water level in the spring drought and dry seasons of Poyang Lake is critical in evaluating the aquatic ecosystem health of the lake. Hence, the lowest water level anomalies during the dry season and the mean water level anomalies during the rising season are determined to characterise the lowest water level (dry season) and spring drought (rising season) of Poyang Lake.

Poyang Lake begins to recede in October and rise in April, as the flood season starts in June (Hu et al., 2007) whilst the dry season occurs from December to March the following year. The lowest water level anomaly during the dry season is expressed by the difference between the lowest water level of the dry season (December-March) and the mean value of the lowest water level of the dry season over multiple years. Meanwhile, the rising season anomaly is expressed by the difference between the mean water level of the rising season (April-May) and the mean of mean water level of the rising season over multiple years.

\section{Water environment indicators}

As discussed in the previous section (2. Hydrological indicators), water environment is one of the four elements of habitat, as its condition can directly impact the growth of aquatic organisms. Therefore, water environment is selected as another indicator of habitat. In the 1980s, Poyang Lake has entered the mesotrophic stage (Cheng and Li, 2006); at present, it is in light eutrophic stage (as reported by Environmental Bulletin in 2013). Water quality has gradually deteriorated because total nitrogen and total phosphorus have both exceeded the standard values. Eutrophication is one of the key issues of Poyang Lake and hence an important aspect of aquatic ecosystem health assessment. Here, the comprehensive nutrition state index (labelled as TLI) is selected as the indicator for the nutrition status in the aquatic ecosystem health assessment index of Poyang Lake. 
In summary, the aquatic ecosystem health assessment index system of Poyang Lake is constructed from three perspectives, namely, aquatic organism elements, hydrological elements and water environment elements (Table 2).

Table 2. Aquatic ecosystem assessment index of Poyang Lake

\begin{tabular}{|c|c|c|c|c|c|}
\hline $\begin{array}{l}\text { Objective } \\
\text { layer }\end{array}$ & $\begin{array}{l}\text { Element } \\
\text { layer }\end{array}$ & Index layer & Index explanation & Index calculation method & $\begin{array}{l}\text { Determination } \\
\text { method of index } \\
\text { thresholds }\end{array}$ \\
\hline \multirow{5}{*}{ 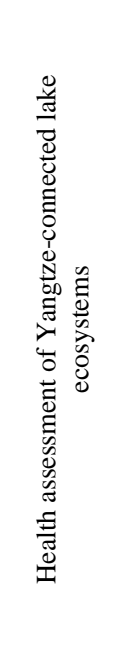 } & \multirow{2}{*}{$\begin{array}{l}\text { Aquatic } \\
\text { organism } \\
\text { elements }\end{array}$} & $\begin{array}{c}\text { Ratio of } \\
\text { cyanobacteria } \\
\text { biomass to diatom } \\
\text { biomass }(\mathrm{CB} / \mathrm{DB})\end{array}$ & $\begin{array}{l}\text { Characterise the primary } \\
\text { productivity status of lakes } \\
\text { and ecosystem succession }\end{array}$ & Measure, calculate & $\begin{array}{l}\text { Reference mode } \\
\text { method, } \\
\text { frequency } \\
\text { analysis method }\end{array}$ \\
\hline & & $\begin{array}{l}\text { Diversity index of } \\
\text { macrozoobenthos } \\
\text { (DI) }\end{array}$ & $\begin{array}{l}\text { Characterise the features } \\
\text { of macrozoobenthos and } \\
\text { reveal the changes of } \\
\text { ecosystem }\end{array}$ & $D I=\sum_{j=1}^{m}\left(N_{i} / N\right) \log \left(\frac{N_{i}}{N}, 2\right)$ & $\begin{array}{l}\text { Normative } \\
\text { standards and } \\
\text { analogies }\end{array}$ \\
\hline & \multirow{2}{*}{$\begin{array}{c}\text { Hydrological } \\
\text { elements }\end{array}$} & $\begin{array}{l}\text { Lowest water level } \\
\text { anomaly during } \\
\text { dry season } \\
\text { (LWLa-D) } \\
\end{array}$ & $\begin{array}{c}\text { Evaluate the characteristics } \\
\text { of lowest water level } \\
\text { during dry season }\end{array}$ & $\begin{array}{c}\text { Difference between lowest water level } \\
\text { in December-March and mean of } \\
\text { lowest water level over multiple years } \\
\text { during dry season }\end{array}$ & $\begin{array}{c}\text { Special value } \\
\text { method, } \\
\text { frequency } \\
\text { analysis method } \\
\end{array}$ \\
\hline & & $\begin{array}{l}\text { Mean water level } \\
\text { anomaly during } \\
\text { rising season } \\
\text { (MWLa-R) }\end{array}$ & $\begin{array}{c}\text { Evaluate the characteristics } \\
\text { of water level during rainy } \\
\text { season (spring drought or } \\
\text { not) }\end{array}$ & $\begin{array}{c}\text { Difference between mean water level } \\
\text { in April-May and the mean of mean } \\
\text { water level over multiple years during } \\
\text { rising season }\end{array}$ & $\begin{array}{l}\text { Special value } \\
\text { method, } \\
\text { frequency } \\
\text { analysis method }\end{array}$ \\
\hline & $\begin{array}{c}\text { Water } \\
\text { environment } \\
\text { elements }\end{array}$ & $\begin{array}{l}\text { Trophic state index } \\
\text { (TLI) }\end{array}$ & $\begin{array}{l}\text { Characterise the state of } \\
\text { nutrition of lakes }\end{array}$ & Reference (Wang et al., 2002) & $\begin{array}{l}\text { Normative } \\
\text { standards and } \\
\text { analogies }\end{array}$ \\
\hline
\end{tabular}

TLI: Trophic state index; CB/DB: Ratio of cyanobacteria biomass to diatom biomass; DI: Diversity index of macrozoobenthos; LWLa-D: Lowest water level anomaly during dry season; MWLa-R: Mean water level anomaly during rising season

\section{Determining the aquatic ecosystem health assessment thresholds of Poyang Lake}

The threshold proposed by Robert in the 1970s (May, 1997) refers to the set of thresholds and breakpoints of multiple stable states based on the characteristics and functions of the ecosystem. The methods to determine thresholds include normative standards and analogies, special value methods, statistical models, mathematical models, physical models, etc. The threshold determination methods for specific indicators are shown in Table 2.

\section{Ratio of cyanobacteria biomass to diatom biomass}

Few related researches on the indicator exist at present. In this study, health assessment thresholds are determined by performing the time reference mode method and the frequency method. Figure 2 shows the CB/DB ratio from 1984 to 2013. The values have increased year by year, and the ratio in 2013 is larger than that in 2012 . By taking the state of Poyang Lake in 1984 as the reference state of 'good' (maximum value 1.22 , minimum value 0.004 , average value 0.16 , median value 0.04 ), and combined with the histogram of the $\mathrm{CB} / \mathrm{DB}$ ratio in the past 30 years (Fig. 3), the thresholds are determined to be as follows: 'poor' $(>0.6)$, 'moderate' $(0.4-0.6)$ and 'good' $(<0.4)$.

\section{Diversity index of macrozoobenthos}

The diversity index of macrozoobenthos has been widely used in water quality assessments (Lu, 1985; Lv et al., 2009; Miler et al., 2013; Xiong et al., 2003). 
According to the Aquatic Biomonitoring Manual (State Environmental Protection Agency, 1993), the relationship between ecosystem health status and the macrozoobenthos Shannon diversity index can be divided into four pollution categories: $\mathrm{H}=0$ for 'severe pollution', $0<\mathrm{H}<1$ for 'heavy pollution', $\mathrm{H}=1-2$ for 'medium pollution' , $\mathrm{H}=2-3$ for 'light pollution' and $\mathrm{H}>3$ represents 'clean'. As shown in Figure 4, the diversity index of macrozoobenthos has a normal distribution, and the index with relatively high frequency is $0.8-2$. The aquatic ecosystem health thresholds, which are determined on the basis of existing evaluation criteria and frequency methods, are as follows: 'poor' (0-1), 'moderate' (1-2) and 'good' $(>2)$.

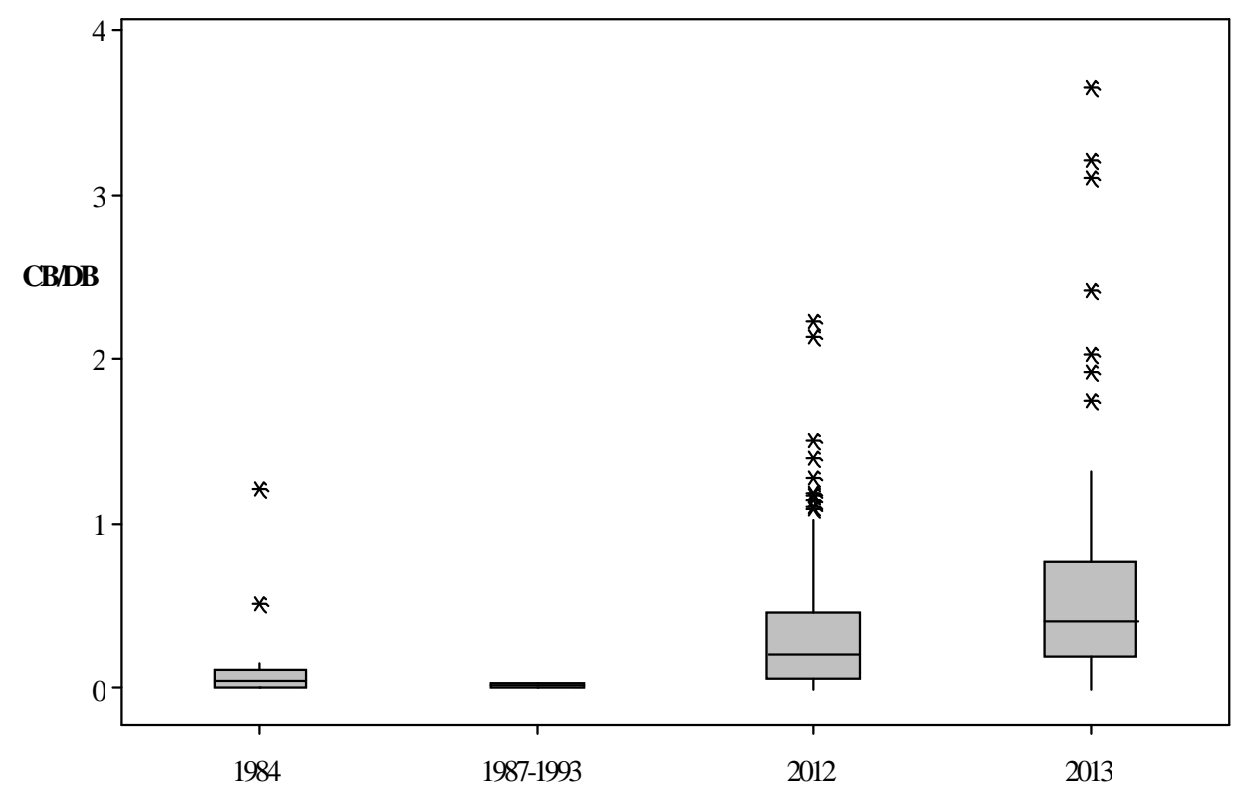

Figure 2. Box-plot of $C B / D B$ ratios of Poyang Lake in the recent 30 years (some data from previous studies (Committee, 1993; Xie et al., 2000))

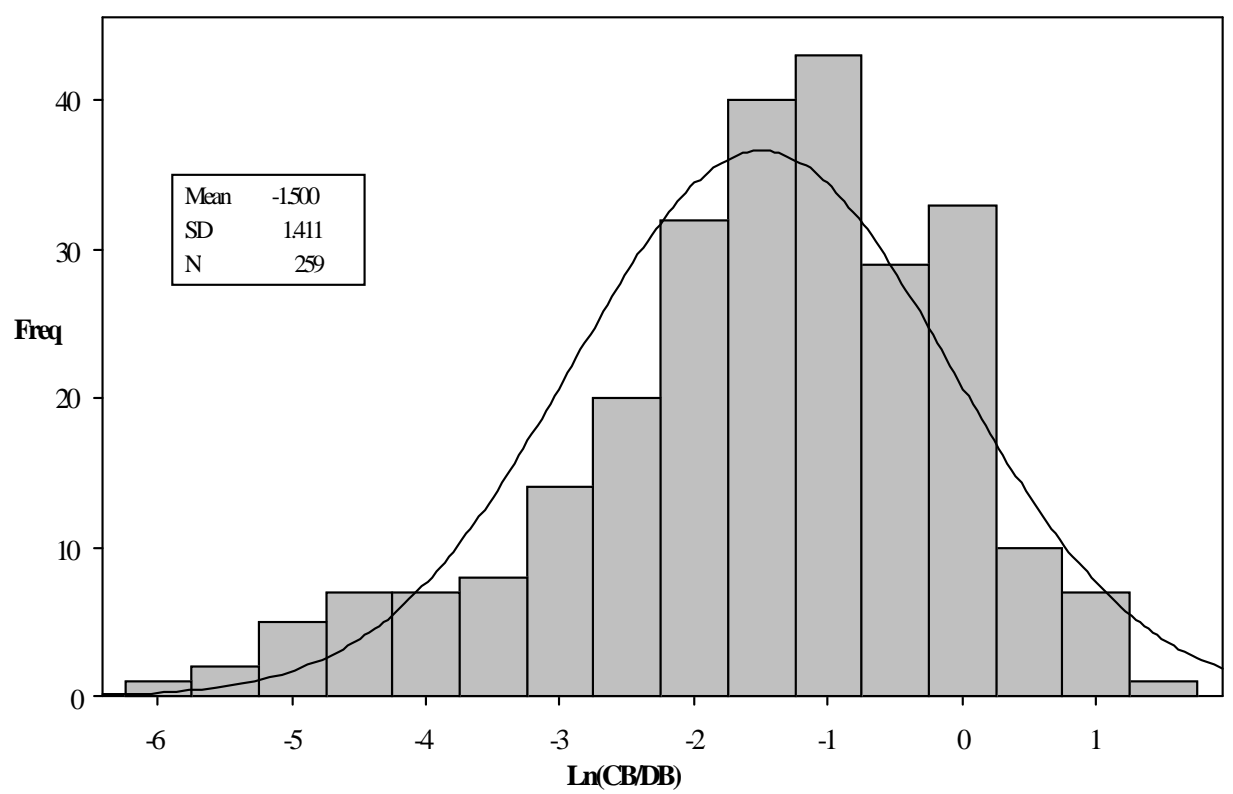

Figure 3. Histogram of $C B / D B$ ratios of Poyang Lake in the recent 30 years 


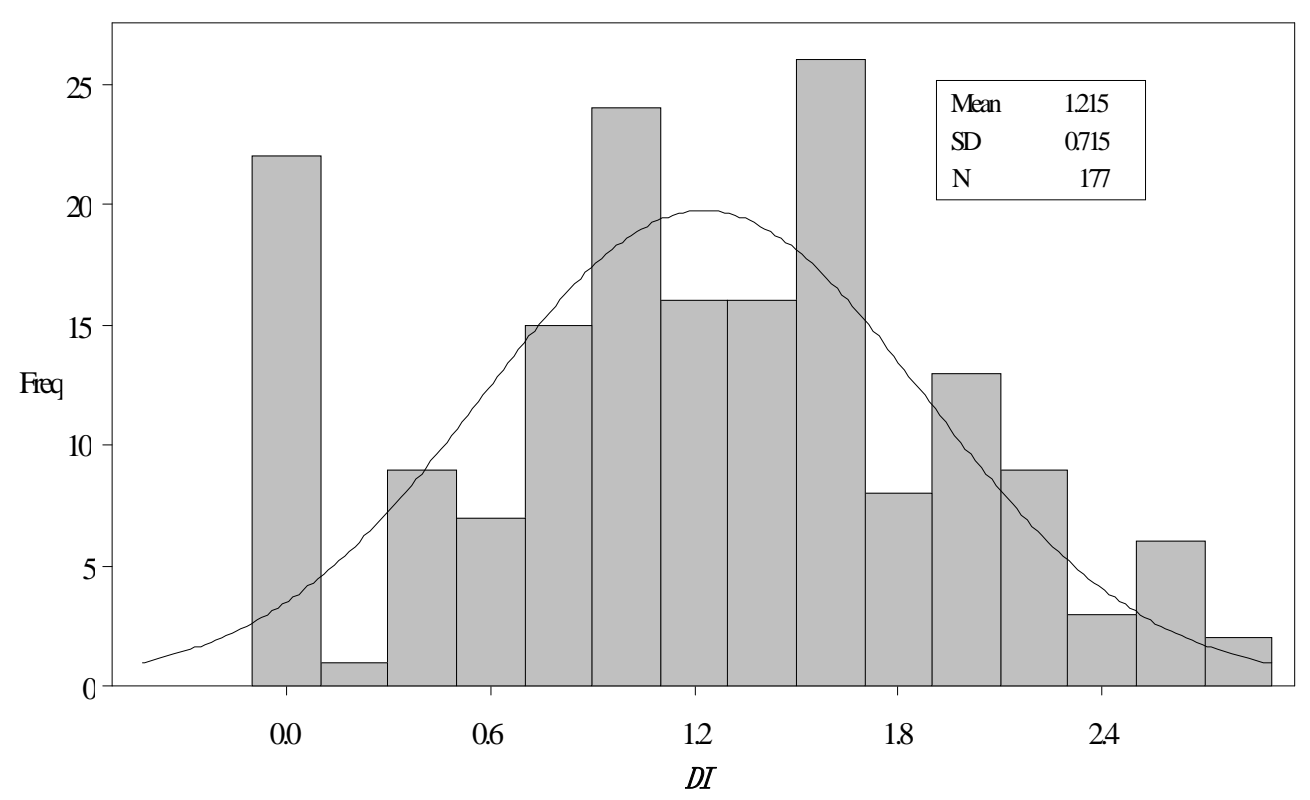

Figure 4. Histogram of diversity index of macrozoobenthos of Poyang Lake in 2012-2013

\section{Lowest water level anomaly during the dry season}

A statistical analysis of water level amplitudes during the dry season of Hukou, Xingzi, Duchang, Wucheng, Tangyin, Kangshan and Boyang stations for Poyang Lake from 1950 to 2011 was conducted. The amplitude variations of the seven stations are not significant, which is in accordance with the normal distribution. The average value is 0 , the standard deviation is $0.7644 \mathrm{~m}$, and the $5 \%$ and $95 \%$ tantiles are $1.34 \mathrm{~m}$ and $-1.18 \mathrm{~m}$, respectively (Fig. 5). In actual situations, the extremes of lowest water level during the dry season affect exposure time and area of wetlands. Exposure time directly affects the development of vegetation on the beach; it may be conducive to vegetative growth and may even result in the growth of new species of wetland ecological vegetation, but wetland degradation may occur if exposure time is too long (Ge et al., 2010). However, an extremely short exposure time over a small exposure area is unfavourable to the growth of wetland plants (Hu et al., 2010) and this will cause a series of ecological problems. Therefore, the extremes of lowest water level anomalies during the dry season signify an unhealthy state. In addition, the water level in Xingzi Station in 2008 was low with amplitude of $-0.95 \mathrm{~m}$ during the dry season. The water levels in Duchang Station in 2008 and 2009 were low (e.g. $7.99 \mathrm{~m}$ in 2009, the lowest in history) with amplitudes of $-1.49 \mathrm{~m}$ and $-1.55 \mathrm{~m}$ during the dry season, respectively. In summary, the range of $1 \times$ standard deviation is determined to be from -0.5 to $0.5 \mathrm{~m}$ ('good'). The $5 \%$ and $95 \%$ tantiles (i.e. based on short plate effect, taking the minimum of absolute value) of $1 \times$ standard deviation is from 0.5 to $1.18 \mathrm{~m}$ and from -0.5 to $-1.18 \mathrm{~m}$ ('moderate') and 'poor' if the value is less than $-1.18 \mathrm{~m}$ or greater than $1.18 \mathrm{~m}$, respectively.

\section{Mean water level anomaly during the rising season}

A statistical analysis on mean water level anomaly during the rising season of Xingzi, Duchang, Hukou, Kangshan, Tangyin, Wucheng and Boyang Stations was conducted. The findings, which accord with normal distribution, show a mean value 
of $0.014 \mathrm{~m}$ and a standard deviation of $1.042 \mathrm{~m}$ (Fig. 6). The $5 \%$ and $95 \%$ tantiles are $1.80 \mathrm{~m}$ and $-1.50 \mathrm{~m}$, respectively. In actual situations, spring drought will affect fish breeding and wetland vegetation. The larger the MWLa-R is, the unhealthier the state will be. In the past 60 years, spring drought occurred five times since 2000, particularly in 2004, 2005, 2008, 2009 and 2011. The mean water level anomalies during the rising season in Xingzi Station for the abovementioned years are -1.44 , $-1.08,-1.53,-0.95$ and $-4.2 \mathrm{~m}$. In Hukou Station, the corresponding anomalies are $-1.35,-1.02,-1.34,-0.67$ and $-3.94 \mathrm{~m}$. In Duchang Station, the corresponding values are $-1.21,-0.80,-1.62,-1.15$ and $-3.24 \mathrm{~m}$. In Wucheng Station, the corresponding values are $-1.01,-1.25,-1.43,-1.12$ and $-3.73 \mathrm{~m}$. In summary, the range of $1 \times$ standard deviation is determined to be from -1.03 to $1.06 \mathrm{~m}$ ('good'). The $5 \%$ and $95 \%$ tantiles (i.e. based on short plate effect, taking the minimum of absolute value) of $1 \times$ standard deviation is from 1.06 to $1.5 \mathrm{~m}$ and from -1.50 to $-1.03 \mathrm{~m}$ ('moderate') and 'poor' if the value is less than $-1.5 \mathrm{~m}$ or greater than $1.5 \mathrm{~m}$, respectively.

\section{Comprehensive nutrition state index}

The comprehensive nutrition index is used to evaluate the nutritional status of water bodies, and it includes the five variables of Chl-a, TN, TP, COD $\mathrm{mn}_{\text {and SD. }}$ and According to the literature (Wang et al., 2002), a TLI of < 30 means 'oligotrophic', 30-50 means 'medium nutrition', and > 50 means 'eutrophication'. The thresholds are determined on the basis of the histogram of the comprehensive nutritional status of Poyang Lake in the past six years (Fig. 7). The thresholds can be determined as follows: 'poor' $(>50)$, 'moderate' $(40-50)$ and 'good' $(<40)$.

In summary, the evaluation thresholds for the aquatic ecosystem health assessment index system of Poyang Lake can be divided into the following three levels: 'good', 'moderate' (sub-healthy) and 'poor' (Table 3).

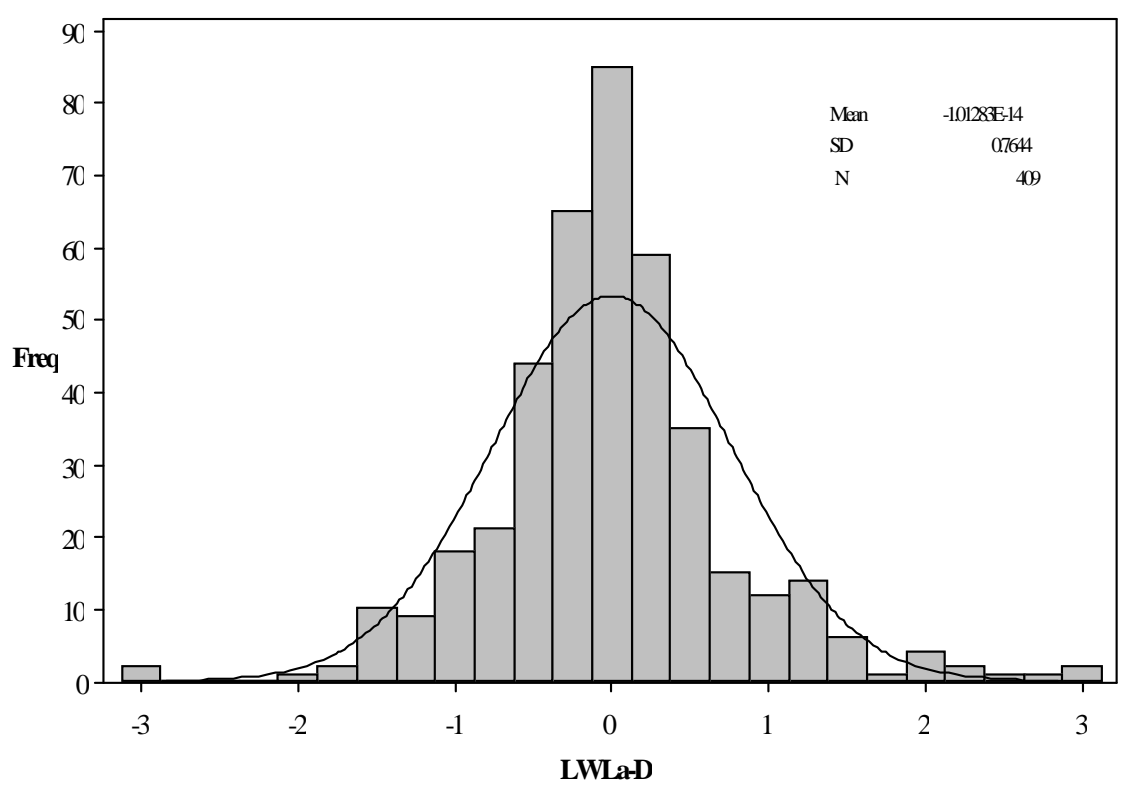

Figure 5. Histogram of lowest water level anomaly during dry season in Hukou, Xingzi, Duchang, Tangyin, Wucheng, Kangshan and Boyang Stations 


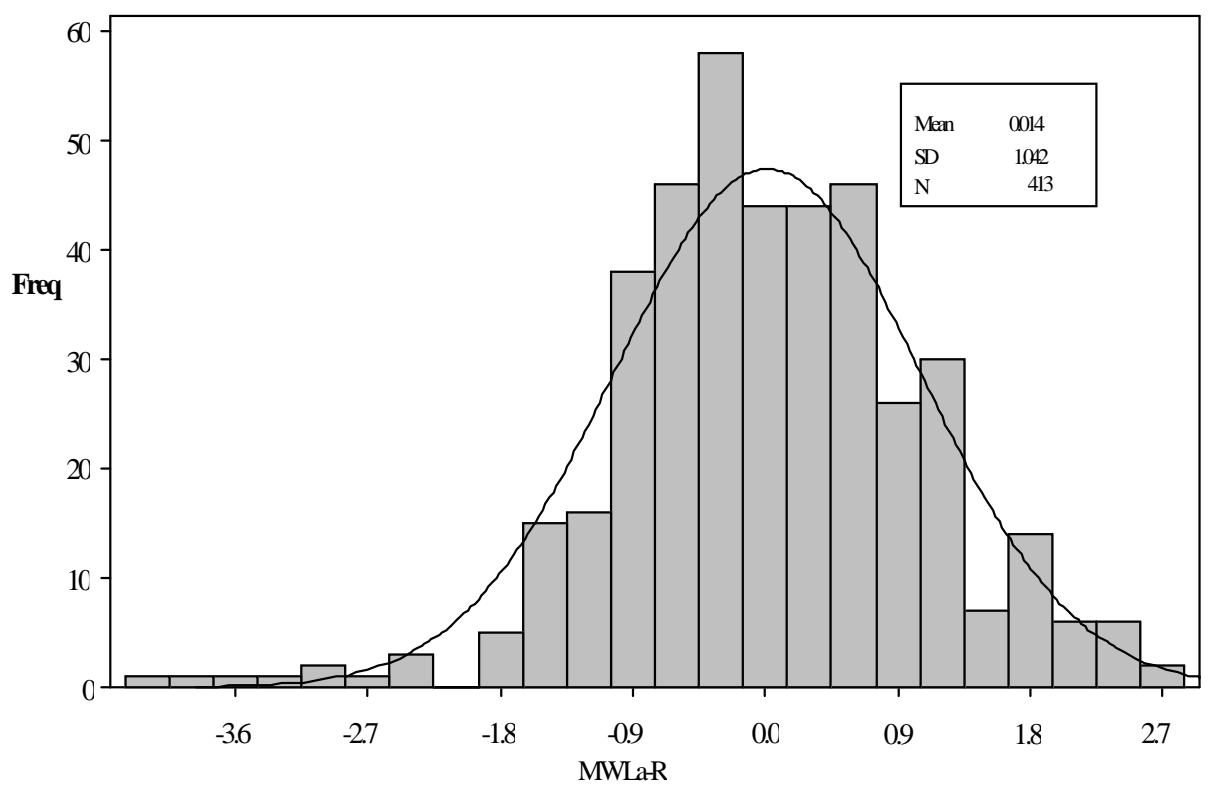

Figure 6. Histogram of mean water level anomaly during rising season in Hukou, Xingzi, Duchang, Tangyin, Wucheng, Kangshan and Boyang Stations

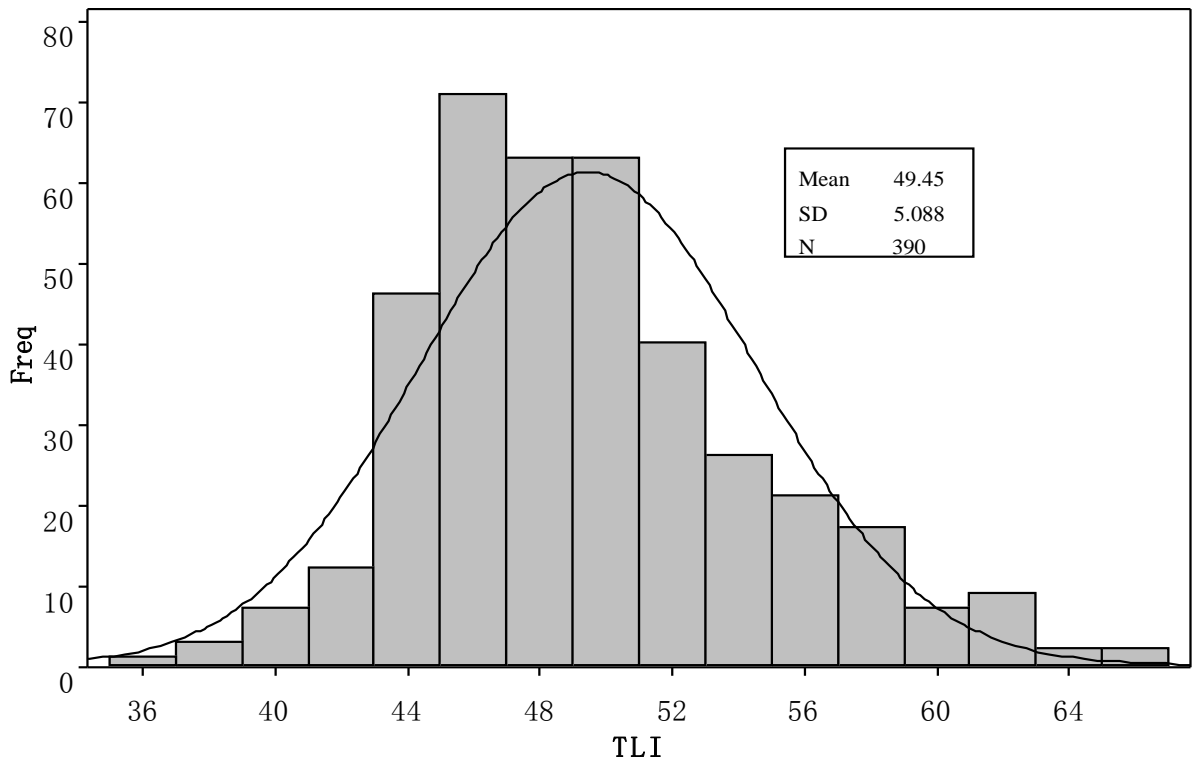

Figure 7. Histogram of TLI of Poyang Lake in 2007-2012

Table 3. Threshold of indicators for Poyang Lake

\begin{tabular}{c|c|c|c}
\hline Indicators/health status & Good & Moderate (sub-healthy) & Poor \\
\hline CB/DB & $\leq 0.4$ & 0.4 to 0.6 & $\geq 0.6$ \\
DI & $\geq 2$ & 1 to 2 & 0 to 1 \\
LWLa-D (m) & -0.76 to 0.76 & 0.76 to $1.18,-0.76$ to -1.18 & $<-1.18,>1.18$ \\
MWLa-R (m) & -1.03 to 1.05 & 1.05 to $1.52,-1.50$ to -1.03 & $<-1.50,>1.52$ \\
TLI & $\leq 40$ & 40 to 50 & $\geq 50$ \\
\hline
\end{tabular}




\section{Conclusions and prospects}

The assessment index system for Poyang Lake presented in this paper comprises the following elements: $\mathrm{CB} / \mathrm{DB}$ ratio and diversity index of macrozoobenthos for the aquatic organism index; lowest water level anomaly during the dry season and mean water level anomaly during the rising season; and the comprehensive nutrition state index with three habitat indicators. The frequency analysis method was conducted, normative standards and analogies were considered, and the special value method was performed to initially determine the thresholds for the health assessment of Poyang Lake's aquatic ecosystem. The three grades ('good', 'moderate' and 'poor') can help provide the research basis for further evaluating the aquatic ecosystem health of the large Yangtze-connected lakes, such as Poyang Lake.

This work is a preliminary study on the index system and the thresholds for the aquatic ecosystem health assessment of large-scale Yangtze-connected lakes. Thus, optimisation and adjustment are still needed. Only the indicators of phytoplankton, macrozoobenthos, and habitat (hydrology and water environment) were considered. In the future, ecological indicators (e.g. migratory fish) and thermodynamic oriented ecological indicators (e.g. ecological energy and structural ecological energy) shall also be covered. Considering that large proportions of fish in these lakes have similar ecological compositions, excluded; however, this approach may have affected the comprehensive assessment of aquatic ecosystem health of Poyang Lake in this study. Moreover, due to the hydrological rhythm ('ample flow, short water') in Poyang Lake, and large aquatic plants mainly appear in few branch area of the lake during the rising season, they are not easily accessible. That is to say, the related data are hardly got. Thus, this study did not consider aquatic plants for the time being, but future research will be conducted to improve this limitation. The indicators on hydrologic elements were determined on the basis of existing data, and further in-depth research and screening can be performed to construct more appropriate indicators. The thresholds of indices were determined on the basis of available data, but some of the important information, especially biological data, was limited. Having access to a wealth of information can help optimise this aspect of the research. In addition, the values of the indicators for Poyang Lake vary greatly with the seasons. Thus, this study only determined the mean threshold value. A further deepening of the research scope is needed for the large Yangtze-connected lakes, such as Poyang Lake, considering their obvious seasonal differences.

Acknowledgements. This study was financially supported by the National Scientific Foundation of China (Grant 41701097), the Key Research Program of the Chinese Academy of Sciences (Grant No. KFZD-SW-318), the National Scientific Foundation of China (Grant 41571107, 41801092) and Natural Science Foundation of Jiangsu province (Grant BK20161118). Special thanks go to the Lake Poyang Laboratory for Wetland Ecosystem Research (PLWER) for providing the data for this study.

\section{REFERENCES}

[1] Aroviita, J. H., Amalainen, H. (2008): The impact of water-level regulation on littoral macroinvertebrate assemblages in boreal lakes. - Hydrobiologia 613: 45-56.

[2] Banerjee, A., Chakrabarty, M., Rakshit, N., Mukherjee, J., Ray, S. (2017): Indicators and assessment of ecosystem health of Bakreswar reservoir, India: an approach through network analysis. - Ecological Indicators 80: 163-173. 
[3] Baumgärtner, D., Mörtl, M., Rothhaupt, K. O. (2008): Effects of water-depth and waterlevel fluctuations on the macroinvertebrate community structure in the littoral zone of Lake Constance. - Hydrobiologia 613(1): 97-107.

[4] Borja, A., Dauer, D. M. (2008): Assessing the environmental quality status in estuarine and coastal systems: comparing methodologies and indices. - Ecological Indicators 8(4): 331-337.

[5] Cai, Y. J., Lu, Y. J., Wu, Z. S., Chen, Y. W., Zhang, L., Lu, Y. (2014): Community structure and decadal changes in macrozoobenthic assemblages in Lake Poyang, the largest freshwater lake in China. - Knowledge and Management of Aquatic Ecosystems 414(09).

[6] Cheng, X. Y., Li, S. J. (2006): An analysis on the evolvement processes of lake eutrophication and their characteristics of the typical lakes in the middle and lower reaches of Yangtze River. - Chinese Science Bulletin 51: 1603-1613.

[7] Committee, C. (1993): Atlas of Poyang Lake. - Science Press, Beijing, China.

[8] Coops, H., Beklioglu, M., Crisman, T. L. (2003): The role of water-level fluctuations in shallow lake ecosystems--workshop conclusions. - Hydrobiologia 506(1-3): 23-27.

[9] Costanza, R., Norton, B. G., Haskell, B. D. (1992): Ecosystem Health: New Goals for Environmental Management. - Island Press, Washington, DC.

[10] Cui, B. S., Yang, Z. F. (2002): Establishing an indicator system for ecosystem health evaluation on wetlands, I. A theoretical framework. - Acta Ecologica Sinica 22(7): 1.

[11] Davies, P. E., Harris, J. H., Hillman, T. J., Walker, K. F. (2010): The Sustainable Rivers Audit: assessing river ecosystem health in the Murray-Darling Basin, Australia. - Marine and Freshwater Research 61(7): 764-777.

[12] De Emiliani, M. O. G. (1997): Effects of water level fluctuations on phytoplankton in a river-floodplain lake system (Paraná River, Argentina). - Hydrobiologia 357(1-3): 1-15.

[13] Ge, G., Ji, W. T., Liu, C. L., Xiong, S., Wu, Z. Q. (2010): Hydraulic project and wetland ecological protection in Poyang Lake. - Resources and Environment in the Yangtze Basin 19(6): 606-613.

[14] Ghosh, D., Biswas, J. K. (2018); Aquatic health indicators: holistic evaluation tools for sustainable management of a tropical oxbow lake ecosystem. - Indian Journal of Fisheries 65(4): 81-92.

[15] Hellsten, S. K. (2001): Effects of lake water level regulation on aquatic macrophyte stands in northern Finland and options to predict these impacts under varying conditions. - Acta Botanica Fennica 171: 1-47.

[16] Hu, M. L. (2009): Charaeteristics of Water Level, Water Environment and Effects on Fish Communication and Migration in the Hukou Area of Poyang Lake. - Nanchang University, Nanchang.

[17] Hu, Q., Feng, S., Guo, H., Chen, G., Jiang, T. (2007): Interactions of the Yangtze river flow and hydrologic processes of the Poyang Lake, China. - Journal of Hydrology 347(1): 90-100.

[18] Hu, Z. P., Ge, G., Liu, C. L., Chen, F. S., Li, S. (2010): Structure of Poyang Lake wetland plants ecosystem and influence of lake water level for the structure. - Resources and Environment in the Yangtze Basin 19(6): 597-605.

[19] Jeppesen, E., Nõges, P., Davidson, T. A., Haberman, J., Nõges, T., Blank, K., ... \& Johansson, L. S. (2011): Zooplankton as indicators in lakes: a scientific-based plea for including zooplankton in the ecological quality assessment of lakes according to the European Water Framework Directive (WFD). - Hydrobiologia 676(1): 279-297.

[20] Jian, M. F., Jian, M. F., Li, L. Y., Wang, S. C., Yu, H. P., Yu, G. J. (2015): Distribution pattern of submerged plants in tropical wetlands of Poyang Lake and its influencing factors of water environment. - Resources and Environment in the Yangtze Basin 24(5): 765-772. 
[21] Kane, D. D., Gordon, S. I., Munawar, M., Charlton, M. N., Culver, D. A. (2009): The Planktonic Index of Biotic Integrity (P-IBI): an approach for assessing lake ecosystem health. - Ecological Indicators 9(6): 1234-1247.

[22] Keto, A., Tarvainen, A., Hellsten, S. (2006): The effect of water level regulation on species richness and abundance of aquatic macrophytes in Finnish lakes. - International Association of Theoretical and Applied Limnology, Proceedings 29: 2103-2108.

[23] Keto, A., Tarvainen, A., Marttunen, M., Hellsten, S. (2008): Use of the water-level fluctuation analysis tool (Regcel) in hydrological status assessment of Finnish lakes. Hydrobiologia 613: 133-142.

[24] Li, B., Yang, G. S., Wan, R. R., Hörmann, G., Huang, J. C., Fohrer, N., Zhang, L. (2017): Combining multivariate statistical techniques and random forests model to assess and diagnose the trophic status of Poyang Lake in China. - Ecological Indicators 83: 74-83.

[25] Liu, X., Qian, K. M., Chen, Y. W. (2015): Effects of water level fluctuations on phytoplankton in a Changjiang River floodplain lake (Poyang Lake): implications for dam operations. - Journal of Great Lakes Research 41(3): 770-779.

[26] Lu, G. Q. (1985): Bio-assessment of Dongting Lake using benthic macroinvertebrates Community Structure. - Environmental Sciences 6(2): 59-63.

[27] Ludovisi, A. (2006): Use of thermodynamic indices as ecological indicators of the development state of lake ecosystems: Specific dissipation. - Ecological Indicators 6(1): $30-42$.

[28] Ludovisi, A., Poletti, A. (2003): Use of thermodynamic indices as ecological indicators of the development state of lake ecosystems. 1. Entropy production indices. - Ecological Modelling 159(2-3): 203-222.

[29] Lv, G. J., Xiong, B. X., Liu, M., et al. (2009): The community structure of macrozoobenthos and water quality assessment on different trophic types of reservoirs. Acta Ecologica Sinica 29(10): 5339-5349.

[30] Lyche-Solheim, A., Feld, C. K., Birk, S., Phillips, G., Carvalho, L., Morabito, G., ... Kolada, A. (2013): Ecological status assessment of European lakes: a comparison of metrics for phytoplankton, macrophytes, benthic invertebrates and fish. - Hydrobiologia 704(1): 57-74.

[31] May, R. M. (1977): Thresholds and breakpoints in ecosystems with a multiplicity of stable states. - Nature 269(5628): 471-477.

[32] Miler, O., Porst, G., McGoff, E., Pilotto, F., Donohue, L., Jurca, T., ... Clarke, R. (2013): Morphological alterations of lake shores in Europe: a multimetric ecological assessment approach using benthic macroinvertebrates. - Ecological Indicators 34: 398-410.

[33] Mjelde, M., Hellsten, S., Ecke, F. (2013): A water level drawdown index for aquatic macrophytes in Nordic lakes. - Hydrobiologia 704(1): 141-151.

[34] Ou, Y. S., Zhan, C., Chen, T. H., Wu, H. L., Wu, X. P. (2009): Species diversity and resource assessment of macrozoobenthos in Poyang Lake. - Journal of Nanchang University (Engineering \& Technology) 31(1): 9-13.

[35] Paerl, H. W., Valdes, L. M., Pinckney, J. L., Piehler, M. F., Dyble, J., Moisander, P. H. (2003): Phytoplankton photopigments as indicators of estuarine and coastal eutrophication. - BioScience 53(10): 953-964.

[36] Qi, L. Y., Huang, J. C., Huang, Q., Gao, J. F., Wang, S. G., Guo, Y. Y. (2018): Assessing aquatic ecological health for Lake Poyang, China: Part II index application. - Water 10(7): 909.

[37] Qi, S. H., Zhang, Q. M., Jiang, F., Liao, F. Q. (2014): Study on the effects on the landscape spatial pattern of the wintering birds' habitat from lake level in Poyang Lake Wetland. - Journal of Natural Resources 29(8).

[38] Rapport, D. J., Whitford, W. G. (1999): How ecosystems respond to stress common properties of arid and aquatic systems. - BioScience 49(3): 193-203.

[39] Schaeffer, D., Herricks, E., Kerster, H. (1988): Ecosystem health: I. Measuring ecosystem health. - Environmental Management 12(4): 445-455. 
[40] Shuai, H., Li, J. B. (2014): Assessment and analysis of comprehensive health in typical years of Dongting Lake System. - Scientia Geographica Sinica 34(2): 170-177.

[41] Solheim, A. L., Rekolainen, S., Moe, S. J., Carvalho, L., Phillips, G., Ptacnik, R., ... Hesthagen, T. (2008): Ecological threshold responses in European lakes and their applicability for the Water Framework Directive (WFD) implementation: synthesis of lakes results from the REBECCA project. - Aquatic Ecology 42(2): 317-334.

[42] Sreeja, J. (2018): Biomonitoring of Paravur Lake in Kerala Using Macro-Invertebrates. In: Rahul, A. K. et al. (eds.) Environmental Pollution. Springer, Singapore, pp. 477-485.

[43] State Environmental Protection Agency (1993): Aquatic Biological Monitoring Manual. Southeast University Press, Nanjing.

[44] Sutela, T., Vehanen, T. (2008): Effects of water-level regulation on the nearshore fish community in boreal lakes. - Hydrobiologia 613(1): 13-20.

[45] Umi, W. A. D., Yusoff, F. M., Aris, A. Z., Sharip, Z. (2018): Rotifer community structure in tropical lakes with different environmental characteristics related to ecosystem health. - Journal of Environmental Biology 39(5): 795-807.

[46] Vanni, M. J. (1987): Effects of nutrients and zooplankton size on the structure of a phytoplankton community. - Ecology 68(3): 624-635.

[47] Wang, M. C., Liu, X. Q., Zhang, J. H. (2002): Evaluate method and classification standard on lake eutrophication. - Environmental Monitoring in China 18: 47-49.

[48] Wu, H. J., Guo, S. L. (2001): The Effect of Hydrological Regime on Phytoplankton Community. - Advances in Water Science 12: 51-55.

[49] Wu, Z., Cai, Y., Liu, X., Xu, C. P., Chen, Y., Zhang, L. (2013): Temporal and spatial variability of phytoplankton in Lake Poyang: the largest freshwater lake in China. Journal of Great Lakes Research 39(3): 476-483.

[50] Xie, Q. M., Li, C. C., Peng, C. L. (2000): primary studies on community ecology of floating algae in Poyang Lake. - Jiangxi Science 18: 162-166.

[51] Xiong, J. L., Mei, X. G., Hu, C. L. (2003): Comparative study on the community structure and biodiversity of zoobenthos in lakes of different pollution states. - Journal of Lake Sciences 15(2): 160-168.

[52] Xu, C. P. (2013): Study on Phytoplankton Community Structure in Lake Poyang. Nanjing Institute of Geography and Limnology, Chinese Academy of Sciences, Nanjing.

[53] Xu, C. P., Li, S. C., Chai, W. B., Chen, Y. W. (2012): A newly recorded cyanobacterial species in water blooms occurred in Lake Poyang-Merismperdia convoluta Breb. Kützing. - Journal of Lake Sciences 24(4): 643-646.

[54] Xu, F., Yang, Z. F., Chen, B., Zhao, Y. W. (2012): Ecosystem health assessment of Baiyangdian Lake based on thermodynamic indicators. - Procedia Environmental Sciences 13: 2402-2413.

[55] Xu, F., Yang, Z. F., Chen, B., Zhao, Y. W. (2013): Development of a structurally dynamic model for ecosystem health prognosis of Baiyangdian Lake, China. - Ecological Indicators 29: 398-410.

[56] Xu, F. L., Dawson, R. W., Tao, S., Cao, J., Li, B. G. (2001): A method for lake ecosystem health assessment: an Ecological Modeling Method (EMM) and its application. - Hydrobiologia 443(1-3): 159-175.

[57] Xu, F. L., Zhao, Z. Y., Zhan, W., Zhao, S. S., Dawson, R. W., Tao, S. (2005): An ecosystem health index methodology (EHIM) for lake ecosystem health assessment. Ecological Modelling 188(2-4): 327-339.

[58] Yang, G. S. (2012): Water issues in the Yangtze River and its formation causes and controling strategies. - Resources and Environment in the Yangtze Basin 21: 821-830.

[59] Yang, G. S., Ma, R. H., Zhang, L., et al. (2010): Lake status, major problems and protection strategy in China. - J. Lake Sci. 22: 799-810.

[60] Zeng, D. H., Jiang, F. Q., Fan, Z. P., et al. (1999): Ecosystem health and sustainable development for human. - Chinese Journal of Applied Ecology 10(6): 751-756. 
[61] Zhang, J. J., Gurkan, Z., Jorgensen, S. E. (2010): Application of eco-exergy for assessment of ecosystem health and development of structurally dynamic models. Ecological Modelling 221(4): 693-702.

[62] Zhang, L., Liu, J. T., Zhang, D. W., Luo, L. G., Liao, Q. G., Yuan, L. J., Wu, N. C. (2018): Seasonal and spatial variations of microcystins in Poyang Lake, the largest freshwater lake in China. - Environmental Science and Pollution Research 25(7): 63006307.

[63] Zhang, L. L., Yin, J. X., Jiang, Y. Z., Wang, H. (2012): Relationship between hydrological conditions and vegetation communities in Poyang Lake national nature reserve of China. - Advance in Water Science 23(6): 768-775.

[64] Zhao, X. F., Tong, P. H. (2013): Ecosystem services valuation based on land use change in a typical waterfront town, Poyang Lake basin, China. - Progress in Environmental Protection and Processing of Resource 295: 722-725. 